\title{
Protein synthesis and secretion by the human endometrium during the menstrual cycle and the effect of progesterone in vitro
}

\author{
S. C. Bell*†, S. R. Patel*, P. H. Kirwan* and J. O. Drife* \\ * Departments of Obstetrics \& Gynaecology and $\dagger$ Biochemistry, University of Leicester, \\ Clinical Sciences Building, Leicester Royal Infirmary, PO Box 65, Leicester LE2 7LX, U.K.
}

\begin{abstract}
Summary. To identify markers of endometrial differentiation specimens of endometrium from the menstrual cycle were incubated in vitro with $\left[{ }^{35} S\right]$ methionine, in the absence or presence of progesterone, and protein synthesis and secretion were studied by fluorographic analysis of one dimensional SDS/gradient polyacrylamide gels. Changes were demonstrated in the rate of synthesis and secretion of a number of endometrial proteins (EP) during the cycle and in response to progesterone. Endometrial proteins were classified into three groups: Group I - synthesized and secreted throughout the menstrual cycle and unaffected by progesterone exposure; Group II - synthesis and secretion associated with histological type of endometrium and unaffected by progesterone exposure, e.g. EP $13\left(M_{\mathrm{r}} 33000\right)$ with proliferative, EP 15 $\left(M_{\mathrm{r}} 28000\right)$ with secretory and EP $14\left(M_{\mathrm{r}} 32000\right)$ with late secretory endometrium; Group III-synthesis and secretion regulated by progesterone exposure irrespective of source of endometrium, e.g. EP $9\left(M_{\mathrm{r}} 54000\right)$ and $11\left(M_{\mathrm{r}} 45000\right)$. The Group II proteins EP 14 and 15 were also the major secretory protein products of endometrium from first and second trimester pregnancy respectively, the native forms referred to as pregnancy-associated endometrial $\alpha_{1}$ - and $\alpha_{2}$-globulins $\left(\alpha_{1}-\right.$ and $\alpha_{2}-$ PEG). We conclude that EP $15\left(\alpha_{2}-\mathrm{PEG}\right)$ represents a human analogue of uteroglobin.
\end{abstract}

\section{Introduction}

The human endometrium under the influence of oestrogen and progesterone exhibits dramatic histological and biochemical alterations during the menstrual cycle (Robertson, 1981). Progesterone is the principal steroid hormone involved in the differentiation of the endometrium during the post-ovulatory secretory phase of the cycle characterized by initiation of glandular epithelial secretion, decidual transformation of stromal fibroblasts and appearance of endometrial granulocytes. It is generally assumed that secretion associated with epithelial differentiation may contribute to the interauterine environment and affect the blastocyst before and during its implantation (O'Grady \& Bell, 1977). Although in many species several specific secretory proteins in luminal fluid have been identified, including uteroglobin (Beier, 1968), studies on human uterine luminal fluid have been less successful (Schumacher, Holt \& Reale, 1979). A number of specific functions have been ascribed to secretory protein products of the endometrium and decidua of laboratory rodents (Bell, 1983a, b).

Many studies have been directed toward the identification of alterations in cytosolic protein synthesis during the human menstrual cycle and its in-vitro regulation by steroid hormones. These studies have consistently detected the increased synthesis of a protein of $M_{\mathrm{r}} 50-55000$ by the secretory endometrium and induced in vitro by progesterone (Hirsch, Fergusson \& King, 1977; O'Grady, Bell, Govan \& Black, 1978; Shapiro \& Forbes, 1978; Iacobelli et al., 1981). However, 
whether this protein is secreted is unknown. More recently, two dimensional polyacrylamide gel electrophoretic techniques have identified a number of proteins synthesized and secreted by the proliferative endometrium during culture (Strinden \& Shapiro, 1983). The rate of synthesis and secretion of a number of these proteins is modulated by exposure to progesterone in vitro. The secretory endometrium has been demonstrated to secrete prolactin (Riddick \& Daly, 1982) and indirect evidence suggests that it secretes the cytosolic protein, "progestagen-dependent endometrial protein", PEP (Joshi, 1983). However, whether these represent major secretory products of this tissue is unknown.

As part of a programme to identify proteins synthesized and secreted by the endometrium, to be used as markers of endometrial differentiation (Bell, 1985), the two major secretory protein products of the endometrium during pregnancy have been characterized, i.e. EP 14 and EP 15 (Bell, Hales, Patel, Kirwan \& Drife, 1985a; Bell, Patel, Hales, Kirwan \& Drife, 1985b). These two proteins, in their native forms termed pregnancy-associated endometrial $\alpha_{1}$ - and $\alpha_{2}$-globulins $\left(\alpha_{1}\right.$ - and $\alpha_{2}$-PEG), exhibited different profiles of synthesis and secretion during pregnancy (Bell \& Drife, 1985). We have now extended this study and examined the synthesis and secretion of proteins by the endometrium during the menstrual cycle and the effect of progesterone in vitro.

\section{Materials and Methods}

Tissues. Tissues were obtained from outpatients attending the Leicester Royal Infirmary. Portions of all tissues were forwarded to the University Department of Pathology for histological examination. Endometrial specimens were obatined from women undergoing laparoscopic sterilization or hysterectomy for benign pelvic conditions. All patients were of proven fertility and had normal menstrual cycles. Patients previously receiving oral contraceptive agents discontinued treatment at least 6 weeks before to operative procedures.

Specimens were classified as follows: early proliferative, Days 5-7; mid-proliferative, Days 8-10; late proliferative, Days 11-14; early secretory, Days 15-18; mid-secretory, Days 19-23 and late secretory-premenstrual, Days 24-28 according to the description of Noyes, Hertig \& Rock (1950) and Wynn (1977).

Incubation and labelling of proteins. Tissues were rinsed in cold saline $(9 \mathrm{~g} \mathrm{NaCl} / 1)$ and, after excess saline was removed onto filter paper on ice, were cut into pieces of about $2 \mathrm{~mm}^{2}$ and weighed. Then $75-100 \mathrm{mg}$ tissue were placed in vials containing incubation medium $(2 \mathrm{ml})$ consisting of Trowell's T-8 (Gibco Europe) supplemented with penicillin $(100 \mathrm{U} / \mathrm{ml})$, streptomycin $(100 \mu \mathrm{g} / \mathrm{ml})$ and fungizone $(0.25 \mu \mathrm{g} / \mathrm{ml})$. Vials were preincubated for $2 \mathrm{~h}$ at $37^{\circ} \mathrm{C}$ and medium was replaced. When sufficient tissue was available, pairs of vials were set up, the medium in one vial being replaced with progesterone-containing medium (dissolved in ethanol and present at $0 \cdot 1 \mu \mathrm{g} / \mathrm{ml}$ ). To label proteins, $40 \mu \mathrm{Ci}\left[{ }^{35} \mathrm{~S}\right]$ methionine (Amersham Int., Bucks, U.K.; sp. act. 800 $\mathrm{Ci} / \mathrm{mmol}$ ) were added to the medium and the incubation was carried out at $37^{\circ} \mathrm{C}$ in an atmosphere of $95 \% \mathrm{O}_{2}-5 \% \mathrm{CO}_{2}$.

After incubation, the secreted proteins were analysed in the incubation medium as previously described (Bell et al., 1985a). Briefly, the medium was removed and centrifuged at $100000 \mathrm{~g}$ for $1 \mathrm{~h}$ and the supernatant fraction stored at $20^{\circ} \mathrm{C}$. Aliquants to be used for gel electrophoresis and fluorography were lyophilized and resuspended in the appropriate volume of sample buffer to achieve adequate loading of radioactivity. To determine incorporation of labelled amino acids into protein, aliquants of medium $(100 \mu \mathrm{l})$ were mixed with bovine serum albumin (BSA) to a final concentration of $0.12 \%(\mathrm{w} / \mathrm{v})$ BSA. Proteins were precipitated by adding $300 \mu \mathrm{l}$ ice-cold $10 \%(\mathrm{w} / \mathrm{v})$ trichloroacetic acid (TCA) and vortexing. The precipitates were kept at $4^{\circ} \mathrm{C}$ for $30 \mathrm{~min}$ and centrifuged at $2000 \mathrm{~g}$ for $5 \mathrm{~min}$. The supernatants were discarded and precipitates washed three times with $300 \mu \mathrm{l}$ ice-cold $5 \%$ TCA. The pellets were then dissolved in $500 \mu l 0.2 \mathrm{M}-\mathrm{NaOH} ; 5 \mathrm{ml}$ scintillation fluid (Fisofluor 1, Fisons Ltd) were added and the tubes were counted in a LKB Beta-Rac Scintillation Counter. 
The colorimetric method of Bradford (1976) was used to determine total proteins using BSA as a reference standard.

Protein separation. For one-dimensional SDS-gradient gel electrophoresis up to $75 \mu$ l volumes of medium (containing up to 100000 c.p.m.) were mixed with an equal volume of buffer containing $\beta$-mercaptoethanol (10\%), SDS (5\%), glycerol (20\%), Trizma $(0.125 \mathrm{M}, \mathrm{pH} 6.8)$ and bromophenol blue $(0.002 \%)$. Samples were heated at $100^{\circ} \mathrm{C}$ for $3 \mathrm{~min}$ and analysed on $1.5 \mathrm{~mm}$ thick $5-15 \%$ acrylamide slab gel (containing $0 \cdot 26-0.82 \%$ bisacrylamide) with a $4.5 \%$ stacking gel (containing $0.12 \%$ bisacrylamide) both containing $0.1 \%$ SDS.

Gels were stained for $1-2 \mathrm{~h}$ in Coomassie blue $\mathrm{G}(0.04 \%$ in $3.5 \%$ perchloric acid, $20 \%$ methanol) then destained for $24 \mathrm{~h}$ using several changes of $5 \%$ acetic acid, $10 \%$ methanol. All gels to be processed for fluorography were soaked in $1 \mathrm{M}$-sodium salicylate, dried, and exposed to Kodak X-Omat X-ray film using Harmer intensifying screens (Chamberlain, 1979). The rates of synthesis and secretion of individual proteins were estimated by: (i) scanning the fluorographs with a densitometer and determining the percentage of total incorporation represented by a particular band on the fluorograph, (ii) and multiplying this percentage by the total rate of incorporation of radioactivity into TCA-precipitable material in the medium.

The molecular weights of proteins were estimated by their mobilities relative to standard proteins of known molecular weight (Sigma Chemical Co., Poole, Dorset, U.K.).

\section{Results}

\section{Radioactive incorporation into medium and identification of secreted proteins}

Incorporation of radioactive methionine into protein was measured during incubations of menstrual cycle endometrium in medium with or without progesterone $(0 \cdot 1 \mu \mathrm{g} / \mathrm{ml})$ in paired vials when sufficient tissue was available. However, during the early proliferative phase, sufficient material did not always permit such analysis and all the specimen was incubated with or without progesterone. Progesterone was included to determine whether the synthesis and secretion of proteins was regulated by progesterone during the culture period. Analysis of radioactivity in TCAprecipitable proteins in the medium revealed that, under these conditions, radioactive proteins were secreted after a lag phase of $2-4 \mathrm{~h}$ and then linearly for $24 \mathrm{~h}$. No effect on total incorporation into secreted proteins in the medium was observed with and without progesterone.

To determine the nature of proteins synthesized and secreted by menstrual cycle endometrium during the incubation, aliquants of culture medium were analysed by one-dimensional SDSgradient polyacrylamide gel electrophoresis and the gels processed for fluorography. Figure 1 is a typical fluorograph of a gel in which culture medium from late proliferative (Day 11) and mid-secretory (Day 21) endometrium specimens after $24 \mathrm{~h}$ in culture were analysed. Track 4 is a culture medium from a first trimester pregnancy endometrium (Week 9-10) for an internal comparison. As in the previous study on protein secretion by early pregnancy endometrium, 17 endometrial proteins were synthesized and secreted by the endometrium during the normal menstrual cycle and, although no protein species was uniquely and specifically associated with any stage of the cycle or pregnancy, dramatic alterations in the quantitative rate of synthesis and secretion of certain protein species were observed during the menstrual cycle and in their response to progesterone in vitro. An analysis of the rates of synthesis and secretion of these proteins was therefore performed in greater detail.

\section{Synthesis and secretion of endometrial proteins EP 13, 14 and 15}

Examination of fluorographs revealed a group of endometrial proteins that appeared to exhibit an increased rate of synthesis and secretion associated with a particular stage of the menstrual 


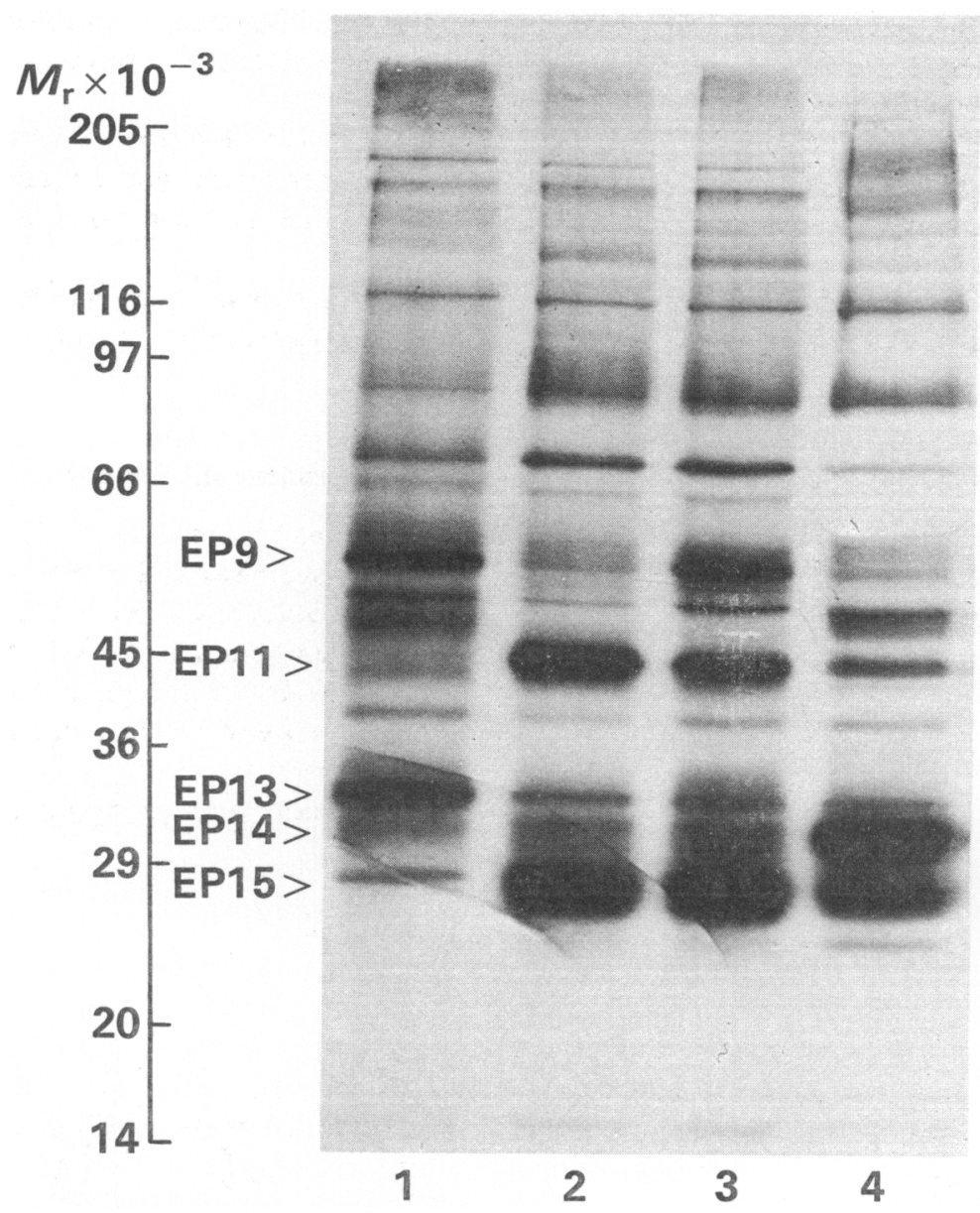

Fig. 1. Fluorograph of one dimensional SDS/gradient PAGE analysis of medium after incubation of endometrium with $\left[{ }^{35} \mathrm{~S}\right]$ methionine. Track 1 , late proliferative endometrium (Day 11) without progesterone; Track 2, mid-secretory endometrium (Day 21) with progesterone; Track 3, secretory endometrium (Day 21) without progesterone; Track 4, first trimester pregnancy endometrium (Week 9-10) without progesterone. Left hand axis refers to $M_{\mathrm{r}}$ of protein standards as visualized by Coomassie Blue staining of gel before processing for fluorography.

cycle, e.g. EP $13\left(M_{\mathrm{r}} 33000\right)$ was associated with the follicular phase, EP $15\left(M_{\mathrm{r}} 28000\right)$ with the luteal phase and EP $14\left(M_{\mathrm{r}} 32000\right)$ with the late luteal phase. The rates of in-vitro synthesis and secretion of these proteins were determined during the menstrual cycle. Aliquants of culture medium were removed at timed intervals, analysed by one dimensional SDS gradient PAGE and fluorography (see 'Materials and Methods'), and the rate was determined from slope of incorporation versus incubation time (Fig. 2). Synthesis and secretion of EP 13 was principally associated with proliferative endometrium (Fig. 3a), with synthesis dramatically declining in the early secretory endometrium $(P<0.01)$. During the follicular phase, this protein represented a major secretory protein of the endometrium (Fig. 1, track 1 ). In contrast, a major secretory protein product during the luteal phase was EP 15 , respresenting up to $35 \%$ of the total $\left[{ }^{35}\right.$ S $]$ methionine incorporated into secretory proteins by the mid to late secretory endometrium (Fig. 3c). Little synthesis and secretion 
was noted by the proliferative or early secretory endometrium. This protein continued to represent a major secretory protein of the endometrium during early pregnancy. However, after Week 6-7, synthesis declined (Bell et al., 1985a).

Although in direct contrast to the situation in pregnancy EP 14 was never a major secretory protein of the endometrium during the menstrual cycle, an increase in synthesis and secretion by the late secretory endometrium containing decidualized endometrium compared to mid-secretory endometrium was observed $(P<0.05)$ (Fig. $3 b)$.

None of the proteins was affected by in-vitro exposure of menstrual cycle endometrium to progesterone under the culture conditions used in this study. Similar results were previously obtained for EP 14 and 15 during early pregnancy (Bell et al., 1985a).

\section{Synthesis and secretion of progesterone-regulated endometrial proteins EP 9 and 11}

The synthesis and secretion of certain endometrial proteins appeared to be affected by shortterm exposure to progesterone in vitro. The in-vitro rate of synthesis and secretion of EP $9\left(M_{\mathrm{r}}\right.$ 54000 ) was decreased by progesterone (decrease of $40.3 \pm 16.6 \%$ for 13 specimens, mean \pm s.d.). It was a major secretory protein of proliferative phase endometrium incubated in the absence of progesterone (Fig. 1, track 1; Fig. 4a) but not in specimens incubated with progesterone (Fig. 4a). In mid-secretory endometrial specimens, although in the presence of progesterone little incorporation into EP 9 was observed (Fig. 1, track 2; Fig. 4a), in paired specimens from the same patient cultured in the absence of progesterone EP 9 synthesis and secretion were pronounced (Fig. 1, track 3; Fig. 4a).

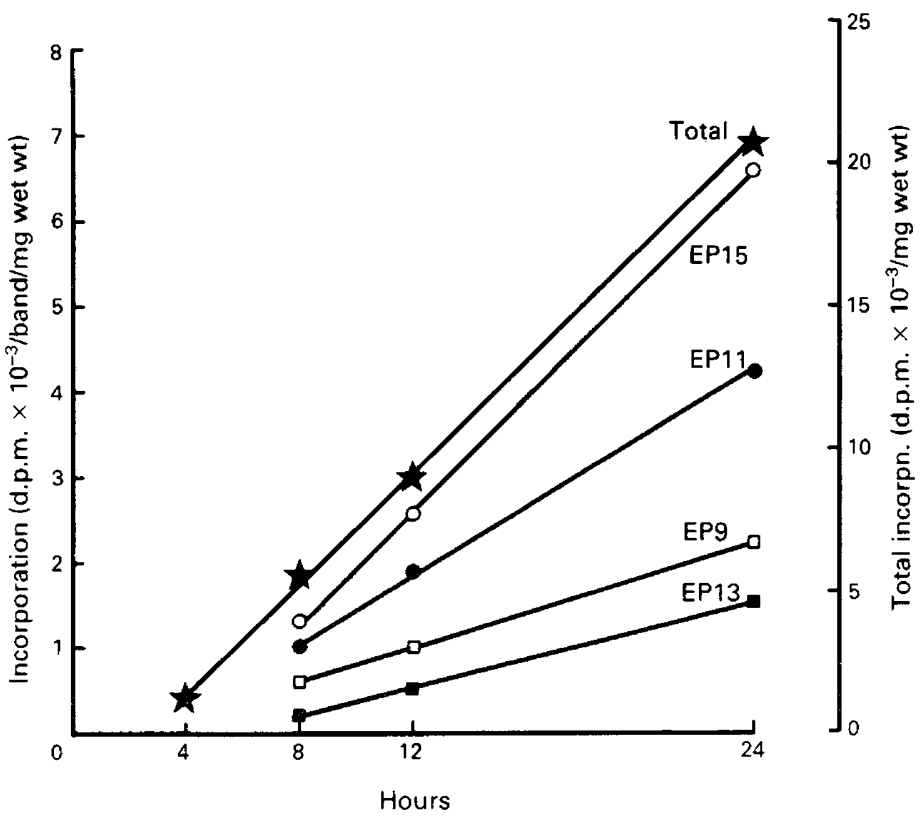

Fig. 2. Estimation of rates of synthesis and secretion of endometrial proteins during incubation of secretory endometrium. Aliquants of culture medium at timed intervals were analysed by SDS/gradient polyacrylamide gel electrophoresis and gels were processed for fluorography. Fluorographs were scanned in a densitometer to obtain an estimate of percentage of total incorporation represented by each protein band. 


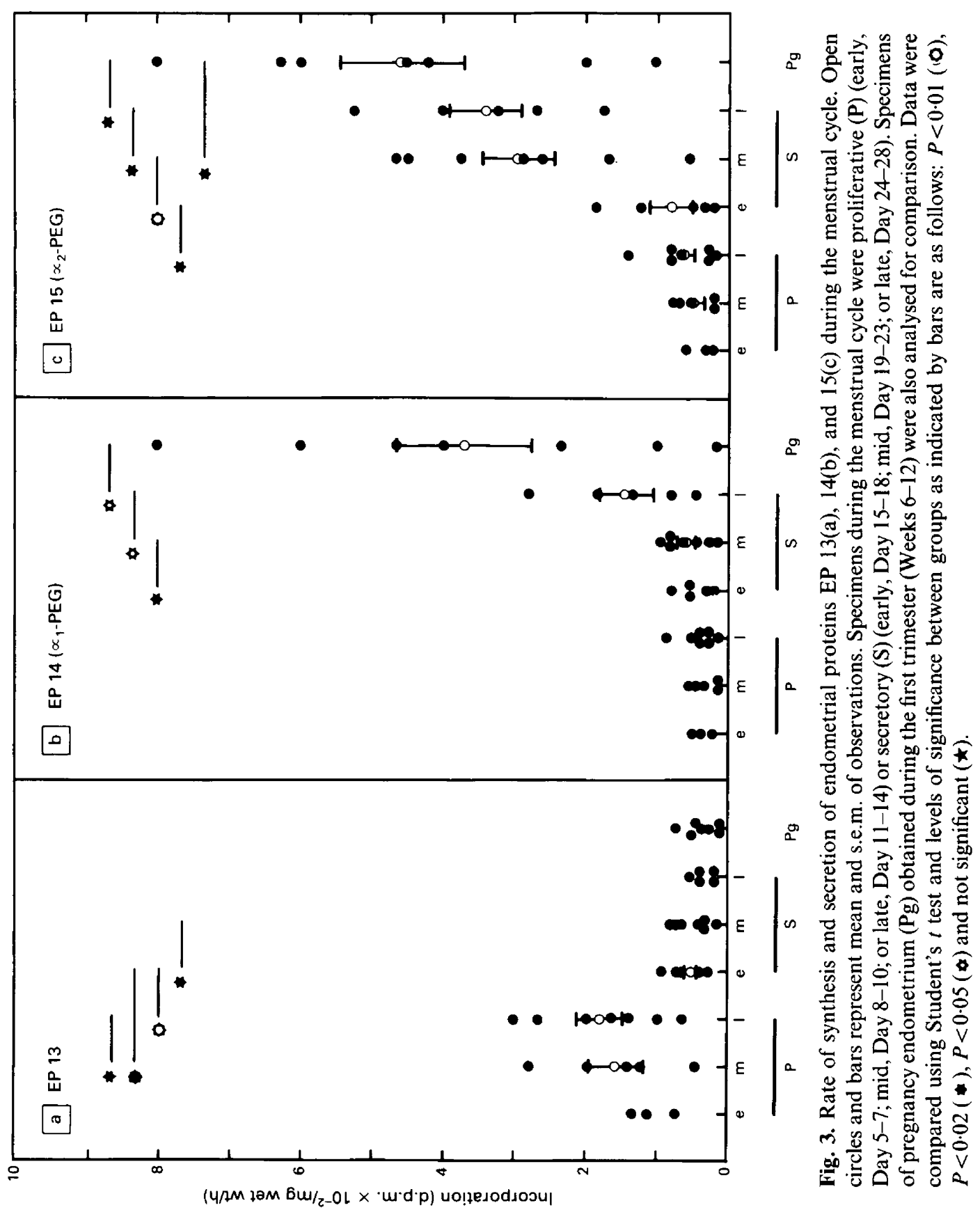




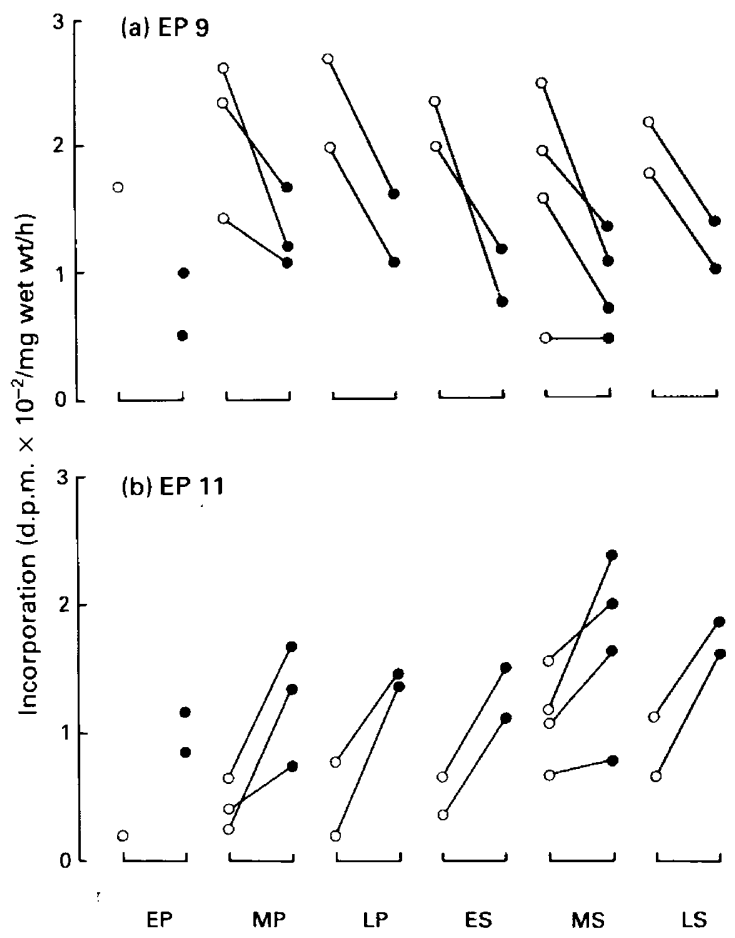

Fig. 4. Rates of synthesis and secretion of endometrial proteins EP 9 (a) and 11 (b) during the menstrual cycle and the effect of progesterone in vitro. Lines between observations represent an experiment performed on paired specimens cultured with $(\Theta)$ or without $(O)$ progesterone. Specimens were early (EP, Days 5-7), mid (MP, Days 8-10) or late (LP, Days 11-14) proliferative endometrium, and early (ES, Days 15-18), mid (MS, Days 19-23) or late (LS, Days 24-28) secretory endometrium.

In direct contrast, EP $11\left(M_{\mathrm{r}} 45000\right)$ synthesis and secretion was increased by short-term exposure to progesterone in vitro (increase by $160 \pm 159 \%$ in 13 specimens, mean \pm s.d.). It was low when proliferative-phase endometrium was cultured in its absence and appeared in its presence (Fig. 1, track 1; Fig. 4b). EP 11 was a major secretory protein product of mid-secretory endometrium incubated with progesterone (Fig. 1, track 2; Fig. 4b) but its synthesis and secretion fell dramatically in its absence (Fig. 1, track 3; Fig. 4b). Under the incubation conditions employed no alteration in the histology of endometrium occurred whether in the presence or absence of progesterone.

\section{Discussion}

This study has demonstrated that, during the normal menstrual cycle, dramatic alterations in the synthesis and secretion of specific proteins occur and also that in-vitro exposure of the endometrium to progesterone can markedly affect the rate of synthesis and secretion of other protein species. We have therefore classified the proteins synthesized and secreted in vitro by the endometrium into three groups (Table 1) which, if detectable in sera, may be of clinical value in assessing endometrial function and differentiation and the in-vivo effect of progesterone upon the endometrium. These proteins are suggested to represent species synthesized and actively secreted and 
Table 1. Classification of endometrial proteins synthesized and secreted by human endometrium during menstrual cycle and pregnancy

\begin{tabular}{llcc}
\hline Group & Protein number & $\begin{array}{c}\text { Associated with } \\
\text { histologically-defined } \\
\text { endometrial type }\end{array}$ & $\begin{array}{c}\text { Affected by short-term } \\
\text { exposure to } \\
\text { progesterone } \text { in vitro }\end{array}$ \\
\hline I & EP 6 & No & - \\
& EP 12 & No & - \\
II & EP 13 & Yes, proliferative & - \\
& EP $14\left(\alpha_{1}-\right.$ PEG $)$ & Yes, decidualized & - \\
& EP $15\left(\alpha_{2}\right.$-PEG) & Yes, secretory & - \\
III & EP 9 & No & $+(\downarrow)$ \\
& EP 11 & No & $+(\uparrow)$ \\
\hline
\end{tabular}

not the result of cell lysis during the incubation since few low molecular weight proteins were observed.

Group II endometrial secreted proteins are those that appear to be associated with a histologically-defined endometrial type, unaffected by short-term in-vitro progesterone exposure, and they include the two major secretory proteins of the endometrium of pregnancy, i.e. EP 14 $\left(\alpha_{1}\right.$-PEG) and EP $15\left(\alpha_{2}\right.$-PEG) (Bell et al., 1985a, b). EP $15\left(\alpha_{2}\right.$-PEG) represents the major secretory protein of the mid- to late secretory endometrium and, because it appeared to be associated with the decidua spongiosa region of the decidua parietalis during pregnancy (Bell et al., $1985 \mathrm{a}$ ), it presumably originates in the secretory glandular epithelium. $\alpha_{2}$-PEG has been purified from a cytosolic fraction of this tissue and exhibits identical properties to the secretory form of $\alpha_{2}$-PEG. In first trimester pregnancy its major route of secretion appears to be into the amniotic fluid (Bell \& Drife, 1985), whereas during the menstrual cycle its profile makes it a prime candidate for a uterine lumen component potentially able to affect the blastocyst before and during implantation. This pattern of synthesis and tissue origin also suggests that $\alpha_{2}$-PEG may be the human analogue of rabbit uteroglobin or blastokinin (Beier, 1968). EP 14 ( $\alpha_{1}$-PEG) was not a major secretory protein during the menstrual cycle and its small increase in synthesis and secretion by the late secretory and premenstrual endometrium is interpreted as due to its association with pre-decidualization occurring during this period. In pregnancy it is the major secretory protein of the decidualized decidua compacta layer of the decidua parietalis (Bell et al., 1985a). The third protein of this group, EP 13, a minor secretory protein product during pregnancy is, however, a major product during the follicular phase of the cycle and may be associated with cell division in the tissue, synthesis and secretion declining during the luteal period of differentiation. Although the synthesis and secretion of none of these proteins were affected by short-term exposure to progesterone in vitro, presumably EP 14 and 15 are ultimately dependent upon this steroid hormone since endometrial differentiation itself is principally progesterone dependent.

Group III endometrial secreted proteins represent proteins for which rate of synthesis and secretion is modulated by progesterone exposure in vitro. Both types of effects are observed in this group with EP 9 being repressed and EP 11 induced by progesterone in vitro. Since these effects are caused within $24 \mathrm{~h}$ in vitro, it is suggested that the rate of synthesis and secretion of those proteins in vivo may closely reflect the endogenous concentration of progesterone to which the uterus is exposed. These effects of progesterone are observed throughout the menstrual cycle independent of the histological type of endometrium and are therefore not linked to progesterone-dependent differentiation. If these proteins are detectable in peripheral sera, they may form the basis for examining the in-vivo response of the endometrium to exogenous progesterone. 


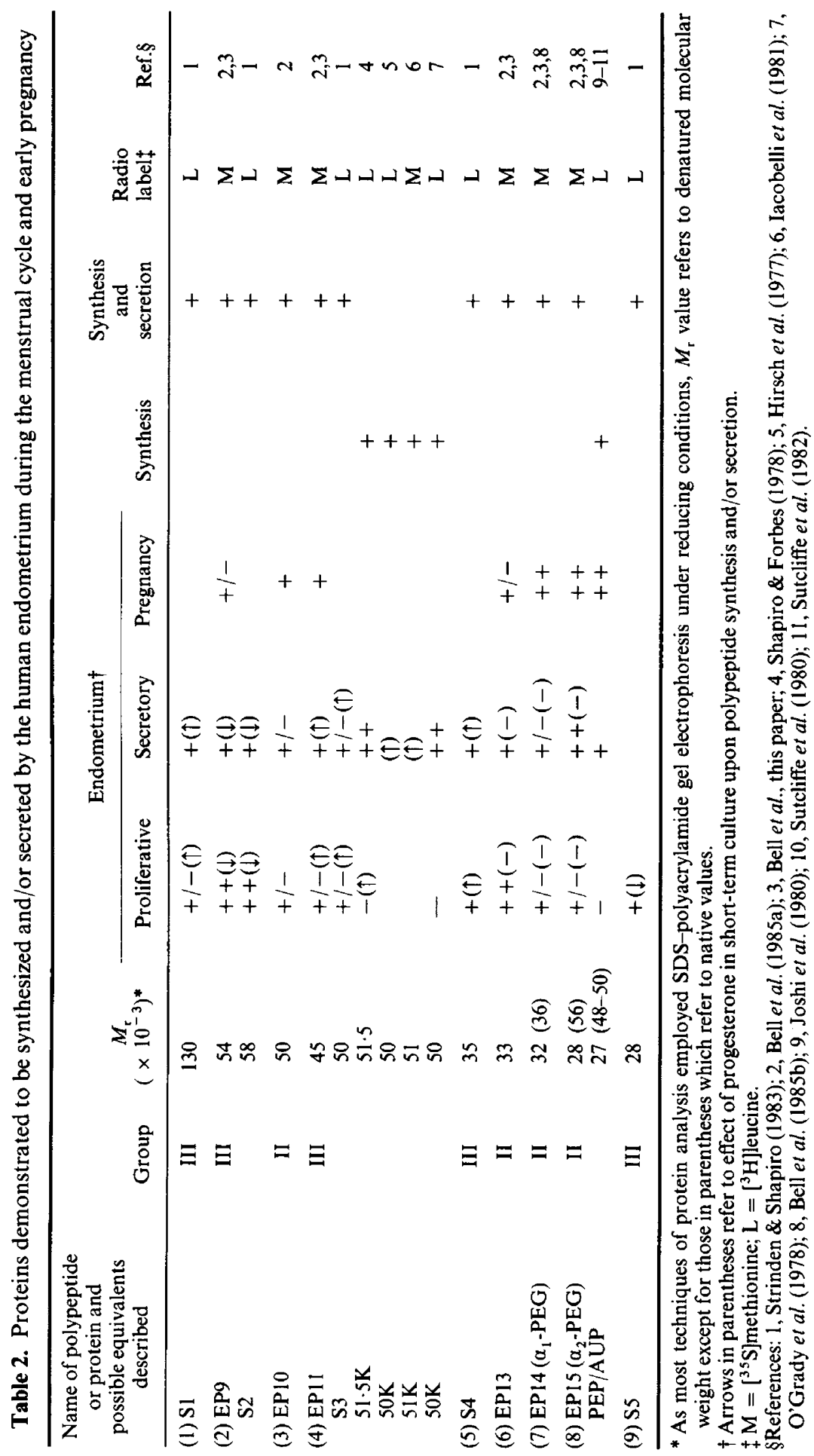


A few studies have been directed towards the identification of secretory proteins of the endometrium by such techniques and more studies have examined the synthesis of cytosolic proteins. In Table 2 the possible relationship between these proteins we have described and those reported has been examined. Two of the progesterone-regulated secretory proteins described by Strinden \& Shapiro (1983) appear similar to those described in this paper, i.e. S2 $\equiv$ EP 9 and S3 $\equiv$ EP 11, and the latter species may indeed represent the secretory form of the progesterone-induced cytosolic protein described by a number of authors (see 'Introduction'). However the lower molecular weight secretory proteins EP 13-15, of which EP 13 and 15 appear from our study to represent major secretory proteins of the menstrual cycle endometrium, were not described in the similar study by Strinden \& Shapiro (1983). This would imply that these proteins possess a low leucine or high methionine content since Strinden \& Shapiro (1983) used $\left[{ }^{3} \mathrm{H}\right]$ leucine as the radiolabelled amino acid. Another possibility is that Strinden \& Shapiro (1983) examined secretory endometrium before the period of substantial synthesis and secretion for EP 14 and 15, i.e. Day 18. Three of the secretory proteins described in the present study also exhibited reduced molecular weights similar to those of 3 cytosolic proteins described by Umapathysivam \& Jones (1981), i.e. EP $11 \equiv 48 \mathrm{~K}$ protein, EP $14 \equiv 36 \mathrm{~K}$ protein and EP $15 \equiv 26 \mathrm{~K}$ protein. Their rates of in-vitro synthesis and secretion also reflected the pattern of total endometrial tissue content during the menstrual cycle and pregnancy described by these authors (see Table 2 ).

The relationship between two of the proteins described in our study and the two soluble proteins extracted from the term placenta, i.e. PP 12 and 14 (Bohn, Kraus \& Winckler, 1982) is of interest. $\alpha_{1}$-PEG (EP 14) and $\alpha_{2}$-PEG (EP 15) have been demonstrated to be biochemically and immunochemically related to PP 12 and PP 14 respectively (Bell \& Drife, 1985). Immunoreactive PP 12 has been detected in soluble extracts of the secretory endometrium during the cycle, although this has not been characterized, and synthesis or secretion have been demonstrated by term decidua (Rutanen et al., 1984, 1985). Similarly, immunoreactive chorionic $\alpha_{2}$-microglobulin (CAG-2) isolated from first trimester placental tissue which is immunochemically identical to PP 14 has been demonstrated in extracts of secretory endometrium (Petrunin, Kozljaeva, Mesrjankina \& Shevchenko, 1980). It is likely that EP $15\left(\alpha_{2}\right.$-PEG) is also similar to PEP since this biochemically similar protein has been detected in extracts of secretory endometrium (Joshi, Bank \& Szarowski, 1981) as well as pregnancy endometrium.

We have now described the major in-vitro secretory protein products of the endometrium during the menstrual cycle and early pregnancy. At present, we have only determined the native forms of the two major secretory proteins during early pregnancy, i.e. EP 15 as $\alpha_{2}$-PEG and EP 14 as $\alpha_{1}$-PEG, although $\alpha_{2}$-PEG has been shown to be the major secretory product during the secretory phase of the menstrual cycle. Both of these proteins are found during pregnancy at highest concentrations in the amniotic fluid (Bell \& Drife, 1985), similar to endometrially-derived prolactin, diamine oxidase (Tujvesson, 1978) and PEP (Joshi, Smith \& Stokes, 1980). In pregnancy, therefore, these proteins are principally secreted into the lumen and traverse the chorion and amnion to gain access to the amniotic fluid, and not into the vascular system. It would be anticiapted that in the cycle $\alpha_{2}$-PEG (EP 15) would therefore be secreted into the uterine lumen. The native forms of the remaining proteins remain to be determined and whether they also contribute to the intrauterine milieu. The identification of two groups of secretory proteins whose rate of synthesis and secretion is either linked with progesterone-dependent differentiation or are progesterone-regulated shortterm offers an opportunity to assess the role of endometrial dysfunction in implantation failure and to examine progesterone-dependent gene expression in the human endometrium.

We thank the medical and theatre staff at the Leicester Royal Infirmary for help with collection of specimens; Miss K. Mann for secretarial assistance; Mrs E. Faulkner for photographic expertise; Dr R. A. Walker (Department of Pathology) for assistance with histology; Professor J. MacVicar for valuable advice and support; and the Trent Regional Health Authority and University of Leicester for financial assistance. 


\section{References}

Beier, H.M. (1968) Uteroglobin: A hormone sensitive endometrial protein involved in blastocyst development. Biochem. Biophys. Acta 160, 289-291.

Bell, S.C. (1983a) Decidualization: regional differentiation and associated function. Oxford Rev. Reprod. Biol. 5, 220-271.

Bell, S.C. (1983b) Decidualization and associated cell types: implications for the role of the placental bed in the materno-fetal immunological relationship. $J$. Reprod. Immunol. 5, 185-194.

Bell, S.C. (1985) Comparative aspects of decidualization in rodents and human: cell types, secreted products and associated function. In Implantation of the Human Embryo, pp. 71-122. Eds R. G. Edwards, J. Purdy \& P. C. Steptoe. Academic Press, London.

Bell, S.C. \& Drife, J.O. (1985) Secretory proteins of the human endometrium and decidua during menstrual cycle and pregnancy: characterization of pregnancyassociated endometrial $\alpha_{1}$ - and $\alpha_{2}$-globulins $\left(\alpha_{1}\right.$ - and $\alpha_{2}$-PEG). In Pregnancy Proteins in Animals, (in press). Ed J. Hau. Walter de Gruyter, Berlin.

Bell, S.C., Hales, M.W., Patel, S., Kirwan, P.H. \& Drife, J.O. (1985a) Protein synthesis and secretion by the human endometrium and decidua during early pregnancy. Br.J. Obstet. Gynaecol. 92, 793-803.

Bell, S.C., Patel, S., Hales, M.W., Kirwan, P.H. \& Drife, J.O. (1985b) Immunochemical detection and characterization of pregnancy-associated endometrial $\alpha_{1}$ - and $\alpha_{2}$-globulins secreted by the human endometrium. J. Reprod. Fert. 74, 261-270.

Bohn, H., Kraus, W. \& Winckler, W. (1982) New soluble placental tissue proteins: their isolation, characterization, localization and quantification. Placenta, Suppl. 4, 67-81.

Bradford, M.M. (1976) A rapid and sensitive method for the quantitation of microgram quantities of protein utilizing the principle of protein-dye binding. Analyt. Biochem. 72, 248-254.

Chamberlain, J.P. (1979) Fluorographic detection of radioactivity in polyacrylamide gels with the watersoluble fluor, sodium salicylate. Analyt. Biochem. 98, 132-135.

Hirsch, P.J., Fergusson, I.L.C. \& King, R.J.B. (1977) Protein composition of human endometrium and its secretion at different stages of the menstrual cycle. Ann. N. Y. Acad. Sci. 286, 233-245.

Iacobelli, S., Marchetti, P., Bartoccioni, E., Natoli, V., Scambia, G. \& Kaye, A.M. (1981) Steroid-induced proteins in human endometrium. Molec. cell. Endocr. 23, 321-331.

Joshi, S.G. (1983) A progestagen-associated protein of the human endometrium: basic studies and potential clinical applications. J. Steroid Biochem. 19, 751-757.

Joshi, S.G., Smith, R.A. \& Stokes, D.K. (1980) A progestagen-dependent endometrial protein in human amniotic fluid. J. Reprod. Fert. 60, 317-321.

Joshi, S.G., Bank, J.F. \& Szarowski, D.H. (1981) Radioimmunoassay for a progestagen-associated protein of the human endometrium. J. clin. Endocr. Metab. 52, 1185-1192.
Noyes, R.W., Hertig, A.T. \& Rock, J. (1950) Dating the endometrial biopsy. Fert. Steril. 1, 3-25.

O'Grady, J.E. \& Bell, S.C. (1977) The role of the endometrium in blastocyst implantation. In Development in Mammals, Vol 1, pp. 165-243. Ed M. H. Johnson. Elsevier, Amsterdam.

O'Grady, J.E., Bell, S.C., Govan, A.D.T. \& Black, W. (1978) Protein synthesis in human endometrium during the menstrual cycle. J. Endocr. 77, 21-22P.

Petrunin, D.D., Kozljaeva, G.A., Mesrjankina, N.V. \& Shevchenko, O.P. (1980) Detection of chorionic $\alpha_{2}$ microglobulin in the endometrium in the secretory phase of the menstrual cycle and in the male sperm. Akush. Gynekol. U.S.S.R. 3, 22-23.

Riddick, D.H. \& Daly, D.C. (1982) Decidual prolactin production in human gestation. Seminars in Perinatology 6, 229-237.

Robertson, W.B. (1981) The Endometrium. Butterworths, London.

Rutanen, E-M., Koistinen, R., Wahlstrom, T., Sjoberg, J., Stenman, U-H. \& Seppala, M. (1984) Placental protein 12 (PP12) in the human endometrium: tissue concentration in relation to histology and serum levels of PP12, progesterone and oestradiol. Br. J. Obstet. Gynaecol. 91, 377-381.

Rutanen, E-M., Koistinen, R., Wahlstrom, T., Bohn, H., Ranta, T. \& Seppala, M. (1985) Synthesis of placental protein 12 by human decidua. Endocrinology 116, $1304-1309$.

Schumacher, G.F.B., Holt, J.A. \& Reale, F. (1979) Approaches to the analysis of human endometrial secretions. In The Biology of the Fluids of the Female Genital Tract, pp. 115-124. Eds F. K. Beller \& G. F. B. Schumacher, Elsevier, Amsterdam.

Shapiro, S.S. \& Forbes, S.H. (1978) Alterations in human endometrial protein synthesis during the menstrual cycle and in progesterone stimulated organ culture. Fert. Steril. 30, 175-181.

Strinden, S.T. \& Shapiro, S.S. (1983) Progesteronealtered secretory proteins from cultured endometrium. Endocrinology 112, 862-870.

Sutcliffe, R.G., Bolton, A.E., Sharp, F., Nicholson, L.V.B. \& Mackinnon, R. (1980) Purification of human alpha uterine protein. J. Reprod. Fet. 58, 435-442.

Sutcliffe, R.G., Joshi, S.G., Paterson, W.F. \& Bank, J.F. (1982) Serological identity between human alpha uterine protein and human progestagen-dependent endometrial protein. J. Reprod. Fert. 65, 207-209.

Tujvesson, G. (1978) Purification and properties of human amniotic fluid diamine oxidase. Scand. J. clin. lab. Invest. 38, 463-472.

Umapathysivam, K. \& Jones, W.R. (1981) A comparative study of nucleic acid content and electrophoretic analysis of human decidual and endometrial proteins. Eur. J. Obstet. Gynec. Reprod. Biol. 12, 43--57.

Wynn, R.M. (1977) Histology and ultrastructure of the human endometrium. In Biology and the Uterus, 2nd edn, pp. 341-476. Ed R. M. Wynn. Plenum Press, New York.

Received 3 September 1985 